\title{
Information about landscape services affects social network interactions in collaborative landscape adaptation
}

\author{
Paul Opdam ${ }^{1}$ (D)
}

Received: 2 October 2018 / Accepted: 13 May 2019 / Published online: 3 July 2019

(c) The Author(s) 2019

\begin{abstract}
In bridging the gap between environmental science and practice, most attention has been given to the transmission of information from science to practice, and to forms of knowledge coproduction. Much less is known about the impact that environmental knowledge and tools have on social processes within groups of actors engaged in collaborative landscape adaptation. In this essay, I select socio-ecological practice cases from my own experience to reflect on the role the concept of landscape services may have played to influence network building, searching for collaborative solutions and making governance agreements. Four types of influence are identified: (1) Applying the concept of landscape services creates a level playing field for governments, business and citizens which facilitated social network building. (2) When groups of actors were informed about multiple landscape benefits generated by green infrastructure, they recognized that if they seek to increase those benefits, they are mutually interdependent, which motivated them to cooperate. (3) Because landscape services thinking implicates demanding and supplying roles, the concept facilitated the formulation of governance agreements. (4) Collaboratively produced landscape maps indicating where the green infrastructure can best be extended fostered joint action. The essay concludes with recommendations for further research.
\end{abstract}

Keywords Socio-ecological networks $\cdot$ Green infrastructure $\cdot$ Science-practice interface $\cdot$ Impact of environmental science $\cdot$ Knowledge coproduction

\section{Introduction}

The effectiveness of scientific information to enhance socio-ecological transitions towards a sustainable use of land (Turner et al. 2007) has been questioned (Opdam et al. 2018; Van Kerkhoff and Lebel 2006). In a seminal paper on transmitting information to society, Cash et al. (2003) proposed that three characteristics, namely credibility, saliency and legitimacy, interdependently determine how information is accepted and processed by environmental practitioners. Scientists advocated to improve information transmission by interacting with decision makers (Reed et al. 2014; Schuttenberg and Guth 2015; Wyborn 2015) and have reflected on different roles that can be played by scholars in knowledge coproduction (Turnhout et al. 2013). Campbell (2012) added

Paul Opdam

Paul.opdam@wur.nl

Spatial Planning Group, Wageningen University and Research, PO Box 47, 6700 AA Wageningen, The Netherlands another dimension to the debate by pointing out that the analytical approach in science has become too dominant, and that for science to have impact in complex problem-solving, problem analysis needs to be complemented with knowledge synthesis in order to design possible pathways to the future. This emphasis on design as a scientific challenge has also been coined by Nassauer and Opdam (2008).

In this essay, I focus on an argument that has been underrated thus far: we still know little about how environmental information influences the social dynamics in groups of practitioners in environmental management. For example, research on participatory mapping, modelling and scenario planning (e.g. Fagerholm et al. 2012; Jones et al. 2009; Malinga et al. 2013; Raymond et al. 2009) mostly focussed on methods and their outcome, rather than on the impact such collective exercises had on the social network, e.g. how it affects collaborative relations between stakeholders. In their review on the use of ecosystem services maps in decisionmaking, Hauck et al. (Hauck et al. 2013, p. 30) concluded that although many researchers claimed that their work would benefit decision-making, this claim was rarely based 
on evidence gathered during the application of the mapping technique in practice. Research aiming at such evidence is complicated by confounding factors that influence the impact of information, such as values of recipients of the information (Bolderdijk et al. 2013), power relations in the social network (Vink et al. 2013) and network configuration (Barnes et al. 2017).

Here I want to advocate the importance of studies on the impact of scientific information on landscape adaptation processes. If researchers collaborate with local communities that search for ways to adapt their landscape to future challenges, how can scientific information introduced by the researchers influence the way groups of practitioners organize the adaptation process? It has been argued that such impacts may be different in the different phases of a planning process (Opdam et al. 2015a, p. 73). My aim is to challenge scholars to future research on this issue by examples of scientific information having an effect on the performance of actor networks in different phases of landscape adaptation processes. To this purpose, I selected cases my colleagues and I recently had been involved in. With one exception, these cases were situated in The Netherlands, in urban, peri-urban and more rural landscapes. In all cases citizens, researchers and authorities worked together to improve various landscape values and make the landscape better adapted to future challenges. In the next section, I will develop a conceptual framework for this reflective analysis, leading to four moments in the adaptation process for which I will explore which impact scientific information may have had on processes in the social network.

\section{Landscape adaptation as a socio-ecological change process}

Landscape adaptation is conceptualized as a human-induced adjustment of the physical features of the landscape, which originates from a shared desire to increase the value of landscape benefits in the context of future societal needs. Such a physical change might for example entail planting hedges, altering stream beds or changing the water level. Because most cultural landscapes are used and owned by a variety of actors, landscape adaptation requires collaboration. In this section, I identify four phases in the process of landscape adaptation within a socio-ecological system in which information provided by scientists may play a role. The four phases are based on a concept of the socio-ecological network that I will discuss first.

\subsection{System concept}

I consider the (cultural) landscape as the physical result of interacting natural and human-induced processes (Fig. 1).

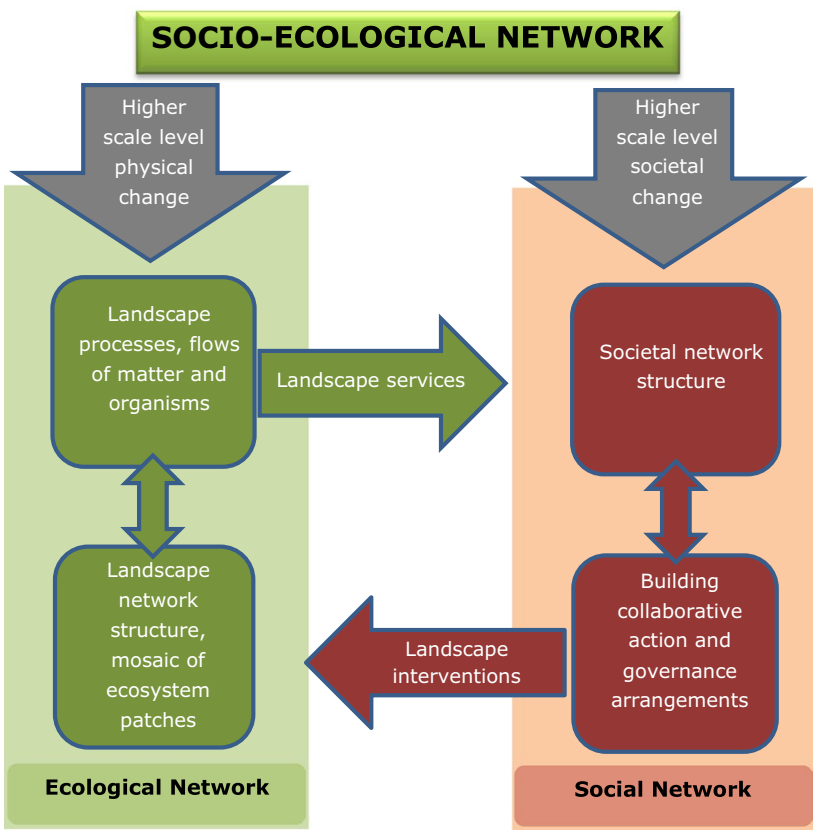

Fig. 1 Representation of the socio-ecological network, showing the interdependence of structure and functioning within the ecological (left) and social (right) component, and two interconnections: provision of landscape services, which are valued within the social network, and interventions in the landscape to improve landscape services provision, which are prepared and implemented within the social network

Over time, this interaction has created a heterogeneous pattern of ecosystem patches, which spatially interact by flows of material, water, energy and species (Tscharntke et al. 2012; Turner and Cardille 2007). Any landscape that is inhabited by humans can be imagined as a spatially heterogeneous socio-ecological system in which a social compartment, the community of people visiting, living and working in that landscape, responds to the benefits delivered (or potentially delivered) by the physical compartment. To emphasize the spatial structure of the socio-ecological system, I will use the term socio-ecological network as a specific type of socio-ecological system (as proposed by Barnes et al. 2017). Network refers to the spatial interactions and interdependencies between locations in the landscape, both in social-cultural and in ecological sense. I will use the term landscape service as a specific type of ecosystem service (Termorshuizen and Opdam 2009; Vallés-Planells et al. 2014), to emphasize that landscape benefits depend on the human-nature interaction, on the spatial dimension and on the heterogeneity of the local landscape (Goldman et al. 2007, p. 336-337).

In a socio-ecological network, humans are actors (agents) initiating change (on top of change caused by external causes such as climate change) and affected by it. Their interventions are driven by the expectation of gaining added value 
against affordable costs. Here I am interested in the role of information in this interaction. Two types of information are particularly relevant (following Opdam et al. 2016, p. 109): information on benefits provided by landscapes to humans and information about how these benefits depend on the ecological functioning and pattern of the landscape. I focus here on these two flows of information about the nature-human relationship within a socio-ecological network. However, landscape areas are open systems affected by many more sources of information from a variety of spatial scale levels. For example, newly available technologies may make harvesting of fruits more profitable, or varying world market food prices affect the decisions local farmers take.

\subsection{Social network}

Collaborative landscape adaptation is the change of physical features of the landscape collectively decided by a mixed group of stakeholders to meet a desired change in the provisioning of landscape services. Such a decision can be taken in formal organizations (for example, government and nongovernment agencies), but also in informal organizations called social networks (Prell et al. 2010, p. 3-4) which are particularly significant in collaborative land management. It is in these social networks that social capital is built up, information is disseminated and people learn to know and trust each other (Munoz-Erickson and Cutts 2016; Barnes et al. 2017).The term social capital describes how individuals in a network use their relationships for their own interest and for the collective good. Social capital embraces relationships based on trust, respect, reciprocity and exchange, and common rules (Adger 2003; Raquez and Lambin 2006, p. 114). In the social network, a capacity of social learning (Newig et al. 2010, p. 5-7) and consensus building (Innes and Booher 1999, p. 413) is developed, leading to bonds between agents being affirmed and to new ideas and practices. Also, social networks are a platform for organizing coordinated interventions in the physical landscape, so it is of importance that the network is large enough and contains a diversity of actors. Here I am interested in whether information about the diversity of landscape services may be of help in building social networks.

\subsection{Collaboration}

Collective action is at the heart of many decisions in the governance of natural resources (Adger 2003, p. 389). Collaboration (Ansell and Gash 2008, p. 545-547) is seen here as a process in a social network characterized by multilateral flows of information, deliberation and shared responsibility of decision-making and implementation. Collaboration has also been defined as a process through which parties who see different aspects of a problem can constructively explore their differences and search for solutions that go beyond their own limited vision of what is possible (Gray 1989, p. 5). The capacity to collaborate is developed within the social network as part of social capital. For example, Fowler and Christakis (2010, p. 5334) have shown that individuals in gaming experiments copy each other's collaborative behaviour, which results in a multiplier effect (a cascade) on collaboration in subsequent groups. Collaborating in a socio-ecological network becomes rewarding if for reaching an individual goal an actor depends on other actors or if an individual goal aligns with a common goal. In the socioecological actors are interdependent in such a way, either because services require landscape-level management of the ecological system or because an effective use of services depends on coordinated demand and organization (Opdam et al. 2016, p. 109-110). But before interdependencies can lead to collaboration, they must be recognized and accepted as such by the actors and brought to bear on a common problem or opportunity to address. Here I am interested in whether information about such interdependencies fosters cooperation.

\subsection{Governance arrangements}

People with different world views often perceive costs and benefits differently. Also, costs and benefits may not be equally distributed among agents and trade-offs may exist between private and public benefits and between short- and long-term gains. Furthermore, many landscape services depend on kilometre-wide areas encompassing many private properties. Hence, there is a need for coordinated interventions and investments as well as rules preventing unwanted adverse effects. Therefore, a socio-ecological system needs some form of governance (Ostrom 2009) based on rules and arrangements developed within the socio-ecological system or developed between governmental bodies and the local community. If information about landscape services influences the relationships between actors in a network, it may also influence the arrangements they make about tasks and responsibilities. For example, if landscape services would facilitate provider-demander relationships, this could lead to arrangements based on delivery and payments.

\subsection{Interventions in the landscape}

The values that may be gained by improving landscape services often depend on the spatial arrangement of landscape units, i.e. the spatial pattern of patches and linear elements in the landscape. For example, services based on biodiversity clearly are dependent on the size, connectivity and heterogeneity of networks of landscape elements over large areas (Opdam et al. 2016, p. 109-110). Spatial interdependencies are also obvious with respect to managing 
water quality and quantity in the landscape as well as in how people perceive and prefer landscapes (Ode et al. 2009, p. 379-381). This means that adapting landscapes for improved services requires coordinated action. Actors from different places across the landscape have to learn as a group how the landscape can most effectively be changed, for example about the range of options that exists to strengthen the green infrastructure of a landscape for the provisioning of natural pest regulation. Also, they have to decide collectively where physical measures based on these options are best located. Here I am interested in how information on the relationship between landscape structure and service provisioning may facilitate such coordinated measures.

\section{Impact of information in four phases of landscape adaptation}

I will present some lessons learned from cases in which information about landscape services has been used in the four phases of landscape adaptation practice distinguished in the previous section. In all cases, the information was provided in the course of a collaboration between scientists and local actors, in which a mixed group of actors made the decisions about goals and solutions. For details about the collaborative process, I refer to the original papers.

\subsection{Building socio-ecological networks}

Applying the landscape services concept helped to strengthen and extend the social network in a local landscape area. In the Hoeksche Waard (The Netherlands) landscape services brought agents together who did not yet cooperate (Steingröver et al. 2010; Opdam et al. 2015a, p. 67-68). Starting with a small core group of farmers who took leadership in a move towards sustainable farming, researchers used the pest regulation service to include more farmers. By coupling this service with the green infrastructure at the landscape scale, they introduced the need of landscape-level collaboration. Next, other services provisioned by this green infrastructure served to bring other groups on board. The water management organization became interested in the surface water purification service, and the local citizens' nature and landscape group (who took care of the nature management of the dikes) recognized the opportunities for improving the conditions for biodiversity and landscape identity. Their engagement was in the farmers' interest: the management of the water banks and the dikes became harmonized to enlarge the green infrastructure on which the farmers were already working to create a more effective and reliable pest regulation service. Thus, scientists used the storyline of landscape services to motivate actors to join the social network.
A similar process in the city of Arnhem (The Netherlands) started with the demand for a more climate proof city centre, in particular aiming at lowering the air temperature during heat waves (Opdam et al. 2015a, p. 70-72). As a solution, researchers proposed to extend the network of green and blue elements and to connect this to the forest lobes that protruded into the city and to the green banks of the river bordering the city centre. This resulted in a map of green infrastructure extensions supported by a planning group of representatives of the municipality, regional authorities and experts. Subsequently, citizen groups, people from the city health group and private project developers became attracted by various other services provided, for example the expected benefits to human health.

Both cases show how a single landscape service was identified by a planning group as the first priority in making the landscape future proof. Connecting this service to a green infrastructure (the ecological network) had the effect of translating the demand into joint action. At that point, in the timeline other groups stepped in, attracted by additional services provisioned by this green infrastructure. By this broadening of the social network, the movement gained in informal power and protruded into a larger part of society.

\subsection{Fostering cooperation}

Although conflicts are a frequent phenomenon in socio-ecological transitions, it is the capacity of collaborative thinking and acting that lies at the basis of any effective socio-ecological change. According to Adger (2003, p. 389), it is "common to all theories of social interaction is the recognition that collective action requires networks and flows of information between individuals and groups to oil the wheels of decision-making". To organize green infrastructure for biodiversity in a region of South Holland, The Netherlands, information about declining wild bee populations was used to trigger a joint motivation to do something. Information about possible actions to improve the conditions for wild bee populations (www.greencircles.nl; www.bijenlandschap.nl) was presented in several workshops that brought together various agents responsible for land management, including representatives of municipalities and private enterprises (Van Rooij et al. 2016). Participants were informed about the minimum area of pollinator reproduction hubs in the green infrastructure that were essential for the persistence of a diversity of pollinators. By discussing the minimum required size of these hubs, the participants realized that they could be achieved only by cooperation with neighbours. So they learned that in order to achieve their goals they were interdependent. By knowing the minimum size and characteristics of reproduction hubs in combination with the new relationships that emerged during the workshop, they became more capable of taking action to achieve the common goal. 
A study by Vos et al. (2018) in de Baaksche Beek area, The Netherlands, offers some insight in how information on interdependencies between stakeholders with contrasting interests resulted in collaboration. A stakeholder network consisting of farmers, water managers and nature managers collectively decided about measures to adapt a mixed agricultural landscape (including nature areas and a stream valley) in view of expected climate-related changes in the water system. The researchers informed three groups in a workshop about mutual benefits of preselected potential measures. The groups chose those measures that best fitted their interests. The stakeholders were also informed about how they were interdependent for achieving the benefits of landscape adaptation. This information was structured in three categories: whether measures were simultaneously beneficial to different sectors (synergy), whether adaptation measures contributed to solving several climate-related problems at the same time (multiple purpose) and whether benefits increased through coordinated landscape-wide implementation (spatial collaboration). More collaboration occurred than was expected on the basis of the individual attitudes that were investigated prior to the workshop. Stakeholders preferred measures that were beneficial to all three sectors involved. Also, when they proposed measures that were not preselected by the researchers, those measures showed the same preference for synergy. However, multiple purpose measures were not preferred. But the stakeholders did mention multiple purpose benefits after selecting the measures, when they were further discussing conditions and expectations. These results suggest that information about the synergy of adaptation measures stimulated an orientation on mutually beneficial solutions, while information on the required landscape-level implementation contributed to the recognition of mutual interdependence.

However, information about shared benefits may be received differently by people with different values and beliefs (Bolderdijk et al. 2013; Meyfroidt 2013, p. 357-358). In an experiment with academic students of Wageningen University, The Netherlands, Opdam et al. (2015b) used the three standard categories of ecosystem services (production, regulation and social-cultural services) as three frames of landscape services, telling different storylines about landscape benefits and related landscape interventions. We concluded that in two of the three storylines (one focussing on enhancing water regulation functions, another one focussing on increasing the value of landscape aesthetics to tourists) the selected measures corresponded to the focus of the storyline. However, a storyline with a focus on the economic value of biomass production did not lead to corresponding measures. We proposed that because the students were educated in environmental management, their interests and values did not align with the economic frame of increased biomass production.

\subsection{Facilitating governance arrangements}

A case study in Gouwe Wiericke, The Netherlands, suggested that stimulating people to think in terms of landscape services made existing relationships based on power more equal and thereby facilitated governance arrangements. Westerink et al. (2017) organized a collaborative planning process as a negotiation between providers (dairy farmers) and beneficiaries (water management authorities and representatives of the provincial government) of landscape services. The rules of negotiation and the joint learning process opened up possibilities for expressing demands, making proposals, experimenting and exploring solutions together. This led the participants away from the power rules of command and control, contestation and conflict in which the same agents had been involved in previous years. In contrast, thinking in terms of demand and provision of landscape services stressed the mutual dependence of the participants and led to new governance arrangements.

\subsection{Enabling people to choose effective measures and where to locate them}

Two examples of using maps as a tool in collaborative decision-making support the conclusion of Hauck et al. (2013, p. 31 ) that to be salient, and legitimate maps should be made in dialogue with map users. If applied as part of a joint learning process, maps of landscape services are a strong tool to explore effective locations for landscape adaptation. In the Hoeksche Waard case (Steingröver et al. 2010), local actors applied design rules that were partially based on their local knowledge. In doing so, they created a map showing where the existing green infrastructure already had the right dimensions to ensure a reliable natural pest regulation in adjacent crops, and where it required extension by flowery field margins and water course banks. They also learned the importance of joint action as the individual managers could see that action on their property was in the interest of the whole community.

In the New Forest, UK, Pouwels et al. (2011) used modelgenerated maps in a mediation between two conflicting interests: species conservation and recreation. With a group consisting of representatives of nature conservation organizations, park management and visitor groups, they explored how the conflict could be mitigated by reallocating the visitor distribution pattern. Interactive use of the maps that gave insight in both the distributions of visitors and of key areas for selected bird species was discussed, and solutions were deliberated in the group, putting the researcher in a role of mediator. This approach facilitated the group to design a jointly preferred visitor pattern that improved the conditions for breeding in the priority birds. 
These two cases suggest that linking required physical conditions to preferred values facilitates collaborative searches for effective interventions in the landscape, provided that they are applied in a cooperative design process in which scientific and local knowledge is integrated.

\section{Suggested impacts of information}

\subsection{Lessons learned}

In this essay, I address the impact of applying information about landscape services in socio-ecological systems. All cases were discussed from a point of view of landscapes as socio-ecological networks. The underlying narrative is that the landscape offers land owners and users a range of potential values that they could benefit from by fostering landscape services. Groups of agents learned about the advantages of such a nature-inclusive landscape management, but also about their interdependencies to achieve nature-inclusive solutions. This narrative implied that people and nature are part of the same spatially structured system, moving away from the "people are threatening valuable cultural landscapes" paradigm towards a relationship based on sustainable use, stewardship, benefits and care. Researchers intervened in these socio-ecological networks by building a collaborative relationship with local actor groups. In dialogue with the actor group, they provided information and facilitated social learning processes including joint problem identification, vision building, design of spatial solutions and joint implementation. With one exception, the cases were done in intensively used agricultural and urban landscapes in The Netherlands. The exception is a case study in the New Forest, UK, a forest landscape with protected species and intensive recreation. In all cases, researchers worked together with practitioners, including planners, authorities, farmers and citizens. So which are the lessons I learned from re-examining these cases?

The first lesson is that applying landscape services can have an impact on social network composition and structure. As a boundary concept in a landscape adaptation process, the use of landscape services facilitates the creation of a level playing field for governments, business and citizens, a common platform for the variety of stakeholders to deliberate landscape values and discuss future benefits. Informing a group of local actors about potential benefits from landscape services has the effect of bringing the broad variety of values and interests under one umbrella and offering stakeholder groups not yet engaged a motive to join the network. These effects make it easier to broaden the scope of the social network and to exchange information and values in building a joint vision.
Second, the cases suggest that collaboration is enhanced by telling the story that individuals and sectors are interdependent because together they can be more effective and more sustainable in achieving added value by investing in landscape services. A joint demand for a variety of services may have stimulated farmers to adapt farming towards producing multiple services. Suppliers learned they are interdependent in ensuring landscape-level conditions for a reliable provision of landscape services. It is this coincidence of individual and collective interests that motivates actors with diverging orientation on landscape benefits to join forces.

The third lesson is that applying the concept of landscape services created a supply-demand relationship, putting actors in a particular role in a one level playing field. This relationship stimulated negotiations based on market mechanisms that fostered a governance arrangement.

The fourth lesson is that information about the spatial relationship between landscape pattern and landscape services may have increased the capacity to organize collaborative change. Maps showing the locations where effective measures could be taken enhanced coordinated decisionmaking about the preferred location for taking measures. Information on dose-impact relationships clarified how much should be done to translate ambitions into concrete adaptation measures.

The terms ecosystem services and landscape services have several characteristics in common, but thus far the former has been typically applied in a technical approach in science, policy analysis and land use change assessment. Recent studies suggest that if applied in collaborative landscape planning as discussed here, the ecosystem services concept can be expected to have similar impacts on the social network. In a review of 27 case studies across Europe, Dick et al. (2018, p. 560) found that in $2 / 3$ of the cases stakeholders perceived more collaboration among involved stakeholders due to the application of ecosystem services information and $40 \%$ thought it had changed how they considered the opinion of others.

\subsection{Discussion}

This essay is not based on a systematic search of the literature on information transfer between science and practice in environmental management. In their review, Opdam et al. (2016, p. 111) concluded that "although there is a sound theoretical basis for the assumption that such information would enhance collaboration, the issue has not been the subject of much scientific research thus far". They summarized examples from empirical research across the world. For example, Rathwell and Peterson (2012) found that municipalities in a stream catchment area in Montreal, Canada, more often collaborated in water management when they also were engaged with recreation services of 
the landscape, which corroborates the idea that multiple landscape services enhance collaboration. In South Africa, Magombeyi et al. (2008) used a river basin game to foster negotiations between upstream and downstream water users which created insight in how downstream groups depend on upstream groups. This insight eventually led to collective water management arrangements, in line with the idea that distinguishing demander and supplier roles enhances governance arrangements. In a co-creation research process with local actor groups in Vietnam (Castella 2009), farmers learned how farm-based decisions (those made by themselves and by their neighbours) were reflected at the landscape scale. The researchers concluded that the farmers' motivation "reached a peak when they realized how they could benefit, collectively and individually". This study illustrates the principle that people are motivated to cooperate by the understanding how individual and collective benefits are interdependent (Ansell and Gash 2008). Guerry et al. (2012) investigated impacts of applying the ecosystem services concept on discussions about developing multiple benefits from marine ecosystems. They concluded (p. 119) that the effect of applying the model InVEST was that discussions broadened "from single-sector perspectives to more comprehensive ones that explore cumulative impacts and benefits and are explicit about trade-offs and win-wins". They state that discussions became less polarized.

The lessons learned are presented here to illustrate the variety of impacts that information may have on the social network in the different phases of the adaptation process. The significance of the lessons is that they suggest potential topics for further research in an underexplored field of socio-ecological practice research. I acknowledge that the lessons have not been identified by a systematic analysis: I rather searched for indications that information had a positive impact, not that an expected impact failed or resulted in conflict. A second limitation is that with one exception the cases are from The Netherlands, so the lessons learned could be biased by typical Dutch cultural characteristics such as a well-developed capacity and willingness to cooperate.

Although in this essay the emphasis is on the impact of information, part of the observed impact might be attributable to the use of participatory tools or the way social learning was fostered. For example, Paolisso et al. (2019) found that a participatory approach enforced the development of a social network. Hence, the collaborative exercises applied in the reviewed cases may have enhanced social interactions irrespective of the information on landscape services (Opdam et al. 2016, p. 111). Also, the group of scientists learned during the various cases and must have developed both knowledge and skills of information exchange. Therefore, part of the impact now attributed to information may have been facilitated by the communication capacities of researchers and/or by specific methods in the participatory process.

\section{Research challenges}

Although environmental scientists have been expressing their concern about the lack of impact of science in practice for long, the mechanisms behind the transmission of environmental information in social processes have not got much scholarly attention. A possible reason for this lack of attention is that investigating these mechanisms requires an integration of social and environmental theories and methods. One of the challenges for further research is to develop a sound theoretical basis for understanding the impact of information in socio-ecological systems, for example theories addressing how people transform information about environmental benefits into sustainable management. Previously I used the theory of planned behaviour (Ajzen 1991) for analysing responses by groups of students to different narratives about landscape services in creating future landscapes (Opdam et al. 2015b). Also of interests is social network theory applied on resource governance (Bodin and Crona 2009; Bodin et al. 2016; Barnes et al. 2017) and collaborative rationality theory (Innes and Booher 2016).

The lessons learned raise many questions for further empirical research. A general aim is to increase our understanding of how information on landscape functioning and the resulting benefits to actors affect their attitudes, motivations and capacities of the social network at the local landscape scale. In such research, it is not the methods and tools for transmitting scientific information that are the aim of investigation, what matters here is the impact their application has on the structure and processes within social networks. For example, if agents are informed about their interdependence in gaining value from the landscape, how does that change their motivation to act together and affect their relationships in the social network? Which new coalitions emerge and do these increase the capacity to change? How does the structure of the social network changes and how do such changes affect information transmission, social learning and resilience (Newig et al. 2010)? These and other questions can be associated with indicators that capture the essential characteristics of a developing socio-ecological network (e.g. Pahl-Wostl 2009; Barnes et al. 2017).

Such questions can be investigated by a mixture of practical case studies, experiments and simulation modelling. In case studies, scientists not only cooperate with practitioners to provide information and facilitate the decision-making, but also make observations as a researcher. While the facilitator and the provider of scientific information are part of the process, the observer keeps distance and focusses on the dynamics in the group. Observers may interview actors 
before and after important steps in the planning process to see if and how their attitudes and motives changed. Or they may record what actors say and how they interact during the workshops and particularly focus on phrases or words that represent expressions of values and beliefs, trust or commitment. They also may document activities and arrangements for which the actor group decides. For this role, social scientists have a broad range of methods available (more details in the case studies discussed above). Another way of exploring this research field is by creating an experimental situation in which information is supplied to a group of actors. Case studies usually do not give the opportunity for experiments. The literature offers inspiring examples of experimental approaches uncovering social network mechanisms (Cavalcanti et al. 2010; Fowler and Christakis 2010; Janssen 2013). Agent-based modelling offers an interesting complement to these empirical approaches. Model simulation offers a tool to extrapolate observed changes in attitude or motivation to changes in the socio-ecological network. For example, based on the Hoeksche Waard case discussed above, Grashof-Bokdam et al. (2017) investigated how social and economic drivers caused a shift from a mono-functional food production landscape with chemical crop protection towards a landscape that in addition provided a natural pest regulation. They found that in the transition towards a multifunctional system the farmers' attitude to achieve more sustainable farming was most important, whereas the farmers' social interaction slowed down the system's turning back during periods of low market prices.

This journal highlights the interaction between science and practice (Xiang 2019, p. 1). I have argued that to understand this interaction we must not only produce methods and tools that are credible, salient and legitimate, but also need to investigate how information alters social interactions in local communities. Practical cases in which scientists cooperate with practitioners offer opportunities for exploring how scientific information interacts with socio-ecological networks in local landscapes.

Open Access This article is distributed under the terms of the Creative Commons Attribution 4.0 International License (http://creativeco mmons.org/licenses/by/4.0/), which permits unrestricted use, distribution, and reproduction in any medium, provided you give appropriate credit to the original author(s) and the source, provide a link to the Creative Commons license, and indicate if changes were made.

\section{References}

Adger WN (2003) Social capital, collective action, and adaptation to climate change. Econ Geogr 79:387-404. https://doi. org/10.1111/j.1944-8287.2003.tb00220.x
Ajzen I (1991) The theory of planned behaviour. Organ Behav Hum Decis Process 50:179-211. https://doi.org/10.1016/07495978(91)90020-T

Ansell C, Gash A (2008) Collaborative governance in theory and practice. J Public Adm Res Theor 18:543-571. https://doi. org/10.1093/jopart/mum032

Barnes ML, Bodin Ö, Guerrero AM, McAllister RJ, Alexander SM, Robins G (2017) The social structural foundations of adaptation and transformation in social-ecological systems. Ecol Soc 22(4):16. https://doi.org/10.5751/ES-09769-220416

Bodin O, Crona B (2009) The role of social networks in natural resource governance: what relational patterns make a difference? Glob Environ Change 19:366-374. https://doi. org/10.1016/j.gloenvcha.2009.05.002

Bodin Ö, Robins G, McAllister RRJ, Guerrero AM, Crona B, Tengö M, Lubell M (2016) Theorizing benefits and constraints in collaborative environmental governance: a transdisciplinary socialecological network approach for empirical investigations. Ecol Soc 21(1):40. https://doi.org/10.5751/ES-08368-210140

Bolderdijk JW, Gorsira M, Keizer K, Steg L (2013) Values determine (in)effectiveness of informational interventions in promoting pro-environmental behavior. PLoS ONE 8(12):e83911

Campbell H (2012) Planning to change the world: between knowledge and action lies synthesis. J Plan Educ Res 32(2):135-146. https://doi.org/10.1177/0739456X11436347

Cash DW, Clark WC, Alcock F, Dickson NM, Eckley N, Guston DH, Jäger J, Mitchell RB (2003) Knowledge systems for sustainable environment. PNAS 100:8086-8091. https://doi.org/10.1073/ pnas. 1231332100

Castella JC (2009) Assessing the role of learning devices and geovisualisation tools for collective action in natural resource management: experiences from Vietnam. J Environ Manage 90:1313-1319. https://doi.org/10.1016/j.jenvman.2008.07.01

Cavalcanti C, Schläpfer F, Schmid B (2010) Public participation and willingness to cooperate in common-pool resource management: a field experiment with fishing communities in Brazil. Ecol Econ 69:613-622. https://doi.org/10.1016/j.ecole con.2009.09.009

Dick J, Turkelboom F, Woods H et al (2018) Sakeholders' perspectives on the operationalisation of the ecosystem service concept: results from 27 case studies. Ecosyst Serv 29:552-565. https:// doi.org/10.1016/j.ecoser.2017.09.015

Fagerholm N, Käyhkö N, Ndumbaro F, Khamis M (2012) Community stakeholders' knowledge in landscape assessments-mapping indicators for landscape services. Ecol Ind 18:421-433. https://doi.org/10.1016/j.ecolind.2011.12.004

Fowler JH, Christakis NA (2010) Cooperative behaviour cascades in human social networks. PNAS 107:5334-5338. https://doi. org/10.1073/pnas.0913149107

Goldman RL, Thompson BH, Daily GC (2007) Institutional incentives for managing the landscape: inducing cooperation for the production of ecosystem services. Ecol Econ 64:333-343. https ://doi.org/10.1016/j.ecolecon.2007.01.012

Grashof-Bokdam C, Cormont A, Polman N, Westerhof E, Franke J, Opdam P (2017) Modeling shifts between mono- and multifunctional farming systems: the importance of social and economic drivers. Landsc Ecol 32:595-607. https://doi.org/10.1007/s1098 0-016-0458-7

Gray B (1989) Collaborating: finding common ground for multi-party problems. Jossey-Bass, San Francisco. ISBN 1-55542-159-8

Guerry AD, Ruckelshaus MH, Arkema KK et al (2012) Modeling benefits from nature: using ecosystem services to inform coastal and marine spatial planning. Int J Biodivers Sci Ecosyst Serv Manag 8:107-121. https://doi.org/10.1080/21513 732.2011 .647835 
Hauck J, Görg C, Varjopuro R, Ratamäki O, Maes J, Wittmer H, Jax K (2013) "Maps have an air of authority": potential benefits and challenges of ecosystem service maps at different levels of decision making. Ecosyst Serv 4:25-32. https://doi.org/10.1016/j. ecoser.2012.11.003

Innes JE, Booher DE (1999) Consensus building and complex adaptive systems. J Am Plan Assoc 65:412-423. https://doi. org/10.1080/01944369908976071

Innes JE, Booher DE (2016) Collaborative rationality as a strategy for working with wicked problems. Landsc Urban Plan 154:8-10. https://doi.org/10.1016/j.landurbplan.2016.03.016

Janssen MA (2013) The role of information in governing the commons: experimental results. Ecol Soc 18(4):4. https://doi. org/10.5751/ES-05664-180404

Jones N, Perez P, Maesham TG, Kelly GJ, d'Aquino P, Daniell KA, Dray A, Ferrand N (2009) Evaluating participatory modeling: developing a framework for cross-case analysis. Environ Manag 44:1180-1195. https://doi.org/10.1007/s00267-009-9391-8

Magombeyi MS, Rollin D, Lankford B (2008) The river basin game as a tool for collective water management at community level in South Africa. Phys Chem Earth 33:873-880. https://doi. org/10.1016/j.pce.2008.06.045

Malinga R, Gordon LJ, Lindborg R, Jewitt G (2013) Using participatory scenario planning to identify ecosystem services in changing landscapes. Ecol Soc 18(4):10. https://doi.org/10.5751/ ES-05494-180410

Meyfroidt P (2013) Environmental cognitions, land change, and socio-ecological feedbacks: an overview. J Land Use Sci 8:341367. https://doi.org/10.1080/1747423X.2012.667452

Munoz-Erickson TA, Cutts BB (2016) Structural dimensions of knowledge-action networks for sustainability. Curr Opin Environ Sustain 18:56-64. https://doi.org/10.1016/j.cosus t.2015.08.013

Nassauer J, Opdam P (2008) Design in science: extending the landscape ecology paradigm. Landsc Ecol 23:633-644

Newig J, Günther D, Pahl-Wostl C (2010) Synapses in the network: learning in governance networks in the context of environmental management. Ecol Soc 15(4):24

Ode Å, Fry G, Tveit MS, Messager P, Miller D (2009) Indicators of perceived naturalness as drivers of landscape preference. $\mathrm{J}$ Environ Manage 90:375-383. https://doi.org/10.1016/j.envma n.2007.10.013

Opdam P, Westerink J, Vos C, De Vries B (2015a) The role and evolution of boundary concepts in transdisciplinary landscape planning. Plan Theory Pract 16:63-78. https://doi. org/10.1080/14649357.2014.997786

Opdam P, Conincx I, Dewulf A, Steingrover E, Vos CC, van der Wal M (2015b) Framing ecosystem services: a way to affect behaviour of actors in collaborative landscape planning. Land Use Policy 46:223-231. https://doi.org/10.1016/j.landusepol .2015 .02 .008

Opdam P, Coninx I, Dewulf A, Steingrover E, Vos C, Van der Wal M (2016) Does information on landscape benefits influence collective action in landscape governance? Curr Opin Environ Sustain 18:107-114. https://doi.org/10.1016/j.cosust.2015.12.006

Opdam P, Luque S, Nassauer JI, Verburg P, Wu J (2018) How can landscape ecology contribute to sustainability science? Landsc Ecol 33:1-7. https://doi.org/10.1007/s10980-018-0610-7

Ostrom E (2009) A general framework for analysing sustainability of socio-ecological systems. Science 325:419-422. https://doi. org/10.1126/science.1172133

Pahl-Wostl C (2009) A conceptual framework for analysing adaptive capacity and multi-level learning proceses in resource governance regimes. Glob Environ Change 19:354-365. https:// doi.org/10.1016/j.gloenvcha.2009.06.001

Paolisso M, Prell C, Johnson KJ, Needelman B, Khan IMP, Hubacek K (2019) Enhancing socio-ecological resilience in coastal regions through collaborative science, knowledge exchange and social networks: a case study of the Deal Island Peninsula, USA. Socio Ecol Pract Res. https://doi.org/10.1007/s42532-019-00010-w

Pouwels R, Opdam P, Jochem R (2011) Reconsidering the effectiveness of scientific tools for negotiating local solutions to conflicts between recreation and conservation with stakeholders. Ecol Soc 16(4): 17

Prell C, Reed M, Racin L, Hubacek K (2010) Competing structure, competing views: the role of formal and informal social structures in shaping stakeholder perceptions. Ecol Soc 15(4):34

Raquez P, Lambin EF (2006) Conditions for a sustainable land use: case study evidence. J Land Use Sci 1:109-125. https://doi. org/10.1080/17474230601079050

Rathwell KJ, Peterson GD (2012) Connecting social networks with ecosystem services for watershed governance: a socio-ecological network perspective highlights the critical role of bridging organizations. Ecol Soc 17(2):24

Raymond CM, Bryan BA, Hatton MacDonald D, Cast A, Strathearn S, Grandgirard A, Kalivas T (2009) Mapping community values for natural capital and ecosystem services. Ecol Econ 68:1301-1315. https://doi.org/10.1016/j.ecolecon.2008.12.006

Reed MS, Stringer LC, Fazey I, Evely AC, Kruijsen JHJ (2014) Five principles for the practice of knowledge exchange in environmental management. J Environ Manag 146:337-345. https://doi. org/10.1016/j.jenvman.2014.07.021

Schuttenberg HZ, Guth HK (2015) Seeking our shared wisdom: a framework for understanding knowledge coproduction and coproductive capacities. Ecol Soc 20(1):15. https://doi.org/10.5751/ ES-07038-200115

Steingröver EG, Geertsema W, Van Wingerden WKRE (2010) Designing agricultural landscapes for natural pest control: a transdisciplinary approach in the Hoeksche Waard (The Netherlands). Landsc Ecol 25:825-838. https://doi.org/10.1007/s10980-010-9489-7

Termorshuizen J, Opdam P (2009) Landscape services as a bridge between landscape ecology 40 and sustainable development. Landsc Ecol 24:1037-1052. https://doi.org/10.1007/s1098 0-008-9314-8

Tscharntke T, Tylianikis JM, Rand TA et al (2012) Landscape moderation of biodiversity pattersn and processes-eight hypotheses. Biol Rev 87:61-685. https://doi.org/10.1111/j.1469185X.2011.00216.X

Turner MG, Cardille JA (2007) Spatial heterogeneity and ecosystem processes. In: Wu J, Hobbs RJ (eds) Key topics in landscape ecology. Cambridge University Press, Cambridge UK, pp. 62-77. ISBN 1139462148, 9781139462143

Turner BL, Lambin EF, Reenberg A (2007) The emergence of land change science for global environmental change and sustainability. PNAS 104:20666-20671

Turnhout E, Stuiver M, Klostermann J, Harms B, Leeuwis C (2013) New roles of science in society: different repertoires of knowledge brokering. Sci Public Policy 40:354-365. https://doi.org/10.1093/ scipol/scs 114

Vallés-Planells M, Galiana F, Van Eetvelde V (2014) A classification of landscape services to support local landscape planning. Ecol Soc 19(1):44. https://doi.org/10.5751/ES-06251-190144

Van Kerkhoff L, Lebel L (2006) Linking knowledge and action for sustainable development. Ann Rev Environ Resour 31:445-477. https://doi.org/10.1146/annurev.energy.31.102405.170850

Van Rooij S, Cormont A, Geerstema W, et al (2016) Een bij-zonder kleurrijk landschap in het Land van Wijk en Wouden: Handreiking 
2.0 voor inrichting en beheer voor bestuivende insecten. AlterraWageningen UR, Report 2720, Wageningen, The Netherlands

Vink MJ, Dewulf A, Termeer C (2013) The role of knowledge and power in climate change adaptation governance: a systematic literature review. Ecol Soc 18(4):46. https://doi.org/10.5751/ ES-05897-180446

Vos CC, Van der Wal MM, Opdam P, Coninx I, Dewulf A, Steingröver E, Stremke S (2018) Does information on the interdependence of climate adaptation measures stimulate collaboration? A case study analysis. Reg Environ Change 18:2033-2045. https://doi. org/10.1007/s10113-018-1306-x

Westerink J, Opdam P, Van Rooij S, Steingröver E (2017) Landscape services as boundary concept in landscape governance: building social capital in collaboration and adapting the landscape. Land Use Policy 60:408-418. https://doi.org/10.1016/j.landusepol .2016.11.006

Wyborn CA (2015) Connecting knowledge with action through coproductive capacities: adaptive governance and connectivity conservation. Ecol Soc 20(1):11. https://doi.org/10.5751/ES-06510 $-200111$
Xiang W-N (2019) Socio-ecological practice research (SEPR): what does the journal have to offer? Socio-Ecol Pract Res 1(1):1-5. https://doi.org/10.1007/s42532-018-0001-y

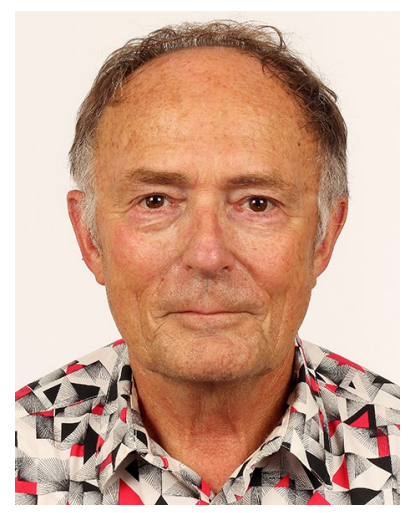

Paul Opdam (1949) is an emeritus professor at Wageningen University \& Research, The Netherlands. Educated as an ecologist, he contributed to understanding habitat fragmentation as a basis for conservation networks. He became interested in integrating landscape ecology in community-based planning and the role of scientific information in sustainability science. 